\title{
Association of allergic disease with subsequent risk of liver cancer: A nation-wide cohort study
}

Ji Ah Kim

Chung-Ang University

Seulggie Choi

Seoul National University Graduate School

Jooyoung Chang

Seoul National University Graduate School

\section{Seogsong Jeong}

Seoul National University Graduate School

Joseph C. Ahn

Division of Gastroenterology and Hepatology, Mayo Clinic, Rochester, Minnesota

Gyeongsil Lee

Seoul National University Hospital

Joung Sik Son

Korea University Guro Hospital

Sang Min Park ( $\nabla$ smpark.snuh@gmail.com )

Seoul National University Graduate School

\section{Research Article}

Keywords: liver cancer, allergic disease, IgE, immunotherapy, Hepatocellular carcinoma

Posted Date: February 8th, 2022

DOI: https://doi.org/10.21203/rs.3.rs-1287865/v1

License: (c) (i) This work is licensed under a Creative Commons Attribution 4.0 International License. Read Full License 


\section{Abstract}

Background : Studies have proposed an inverse association between allergic diseases and cancer risk, but few studies to date have specifically investigated the risk of primary liver cancer (hepatocellular carcinoma, HCC; intrahepatic cholangiocarcinoma, ICC) in patients with or without allergic diseases.

Objective : The aim of this study was to evaluate the association between allergic diseases and risk of developing liver cancer.

Methods: A retrospective cohort study of the Korean National Health Insurance Service database was performed to study 405,512 South Korean adults ages 40 and above who underwent routine health screening after January $1^{\text {st }}, 2005$. All participants were followed for liver cancer diagnosis or death until December $31^{\text {st }}, 2013$. Those who died before the index date, had pre-diagnosed cancer, or did not undergo health screening were excluded. Cox proportional hazards regression was performed to determine the adjusted hazard ratios(aHRs) and 95\% confidence intervals (Cls) for risk of developing liver cancer according presence or absence of atopic dermatitis, asthma and allergic rhinitis.

Results: The aHR $(95 \% \mathrm{Cl})$ for overall liver cancer among allergic patients was 0.72 (0.64-0.81). Allergic patients had significantly reduced risk of HCC (aHR: $0.70,95 \%$ Cl: 0.61-0.81) but not ICC (aHR: 0.99, 95\% Cl: 0.71-1.08). Presence of allergic diseases was associated with significantly lower risk of liver cancer in both patients with (aHR: 0.61, 95\% Cl: 0.470.8 ) or without (aHR: $0.74,95 \%$ Cl: $0.65-0.85$ ) chronic Hepatitis B/C infections. Presence of allergic diseases was associated with significantly lower risk of liver cancer in patients without cirrhosis (aHR: $0.72,95 \% \mathrm{Cl} 0.63-0.82$ ), but not in those with cirrhosis (aHR: $0.98,95 \% \mathrm{Cl} 0.68-1.41$ ). Patients with multiple allergies had even lower risk of liver cancer compared to patients with single allergy.

Conclusion: Patients with allergic diseases have significantly lower risk of developing liver cancer compared to those without allergic diseases, which supports the rationale for immunotherapy as an effective treatment of liver cancer.

\section{Introduction}

Liver cancer is one of the leading causes of cancer incidence and mortality globally. In South Korea, liver cancer is the sixth common cancer and the second largest cause of cancer mortality. ${ }^{1}$ Liver cancer can be classified into primary and metastatic liver cancer. ${ }^{2}$ Types of primary liver cancer include hepatocellular carcinoma (HCC), intrahepatic cholangiocarcinoma (ICC), and other unusual tumors. HCC constitutes nearly $90 \%$ of all primary liver cancer, and usually develops in the background of chronic viral hepatitis or liver cirrhosis from various causes. While HCC is potentially curable via resection, ablation, or liver transplantation if diagnosed at an early stage, HCC is unfortunately most often diagnosed at advanced stages and is associated with very poor prognosis. ${ }^{3}$ Despite the promising recent developments in the role of immunotherapy for HCC, the treatments for advanced HCC remain largely palliative. ${ }^{4}$ Therefore, it is crucial to identify factors that modify the risk of HCC, as they may provide insight into novel preventative or therapeutic options.

Atopic dermatitis, asthma, and allergic rhinitis are the most prevalent allergic diseases worldwide, and their physiology is defined by IgE-mediated immunological hyperresponsiveness. IgE not only mediates the type I hypersensitivity reactions engaged in the pathogenesis of allergic diseases but can also be involved in immune responses against cancer. ${ }^{5,6}$ Several studies have suggested an inverse association between allergic diseases and cancer development. ${ }^{7}$ However, there are only a few studies that investigated the association between allergic diseases and risk of liver cancer, and those studies were limited by the scope allergic diseases investigated, short follow-up, and small sample size ${ }^{8}$ or did not account for strong risk factors such as HBV/HCV infection and cirrhosis. ${ }^{9} 10$ Therefore, the aim of our study was to investigate the association between allergic diseases and the risk of liver cancer using a large population-based cohort from a national database with long term follow-up. 


\section{Methods}

\section{Data Source and Study Design}

In this retrospective cohort study, data was derived from the Korean National Health Insurance Service (NHIS) database which covers information on all forms of healthcare services. In South Korea, the NHIS provides compulsory health insurance for nearly all citizens, accounting for $98 \%$ of the entire population. ${ }^{11}$ Starting at age 40 , all citizens are eligible to undergo a biannual national health screening examination executed by the NHIS.

At the health screening examinations, participants' basic health information including weight, height, blood pressure, fasting serum glucose and total cholesterol level are recorded. Participants also fill out self-reported questionnaires about lifestyle behaviors including smoking status, alcohol consumption and physical activities. The NHIS collects and stores insured personal health information such as sociodemographic features, inpatient and outpatient hospital visits, prescription records of pharmaceutical drugs, and all other laboratory measurements obtained from the national health screening examinations. ${ }^{12}$

This study was conducted upon the approval of the Institutional Review Board of Seoul National University Hospital(IRB number: E-1806-076-951). The requirement for informed consent was waived since the NHIS database is anonymized based on strict confidentiality guidelines before distribution. This study adhered to the principles of the Declaration of Helsinki and all methods were performed in accordance with relevant guidelines and regulations.

\section{Study Population}

In this study, we identified all patients ages 40 and above who underwent the national health screening examinations after the index date of January 1st, 2005. Those who did not undergo health screening examinations, or those with missing values on covariates, pre-diagnosed cancer, death before the index date were excluded. The final study population included 405,512 participants, and all participants were followed for liver cancer or death until December 31st, 2013 (Fig. 1).

\section{Key variables}

Based upon diagnosis and death codes, we defined liver cancer events as having outpatient medical records under related diagnostic codes more than 3 times in a year or being hospitalized for 1 or more days or death under the corresponding ICD-10 codes. In this study, the ICD-10 code for overall liver cancer "C22" was used and "C22.0" for HCC, "C22.1" for ICC were used respectively for further analysis.

The diagnosed history of allergic diseases (atopic dermatitis, asthma, allergic rhinitis) was defined as having outpatients visits with relevant diagnostic codes more than two times or being hospitalized for 1 or more days. Since allergic diseases mostly develop during childhood, we did not wash out previously confirmed cases but measured the incidence of allergic diseases from 2002 to 2005. The ICD-10 codes "L20" for atopic dermatitis, "J45" for asthma, and "J30.1", "J30.2", "J30.3", "J30.4" for allergic rhinitis were used.

Since the infection of either Hepatitis B virus or Hepatitis C virus and liver cirrhosis are major risk factors for liver cancer, we additionally considered those factors as covariates which had to be adjusted. Operational definition of the diagnosed history of HBV/HCV infection and liver cirrhosis was having outpatients more than 3 times or being hospitalized for 1 or more days. The ICD-10 codes “B180”,"B181” for HBV, “B182” for HCV and “1859”, “1982”, “K703”, “K717”, “K746” for liver cirrhosis were used in this study. ${ }^{13}$

\section{Statistical analysis}

Participants were evaluated for adjusted hazard ratios(aHRs) and 95\% Cls for liver cancer risk according to the diagnosed history of three allergic diseases using multivariate Cox proportional hazards regressions. Potential confounding covariates 
are included: history of either HBV or HCV infection(categorical, yes or no), history of liver cirrhosis(categorical, yes or no), age, sex, body mass index $\left(\mathrm{kg} / \mathrm{m}^{2}\right)$, household income(categorical, $1 \mathrm{st}$ (highest), 2nd 3rd, 4th (lowest) quartiles), Charlson comorbidity index, smoking status (categorical, never, former, and current smokers), alcohol consumption(categorical, 0, 0 1, 1-2, 3-4. 5 times per week), physical activity(categorical, 0, 1-2, 3-4. 5-6, and 7 times per week), systolic blood pressure $(\mathrm{mmHg})$, fasting glucose serum $(\mathrm{mg} / \mathrm{dL})$, and total cholesterol $(\mathrm{mg} / \mathrm{dL})$. Body mass index was calculated by dividing the weight in kilograms by the square of height in meters. Household income was derived from the insurance premium and the calculation of Charlson comorbidity index was adapted from a previous study. ${ }^{14}$

Adjusted Hazard ratios of allergic patients in overall liver cancer were mainly calculated and compared with non-allergic patients. Four sub-analyses were then followed. First, aHRs of HCC and ICC were separately calculated. Second, stratified analyses according to several potential covariates were conducted. Third, patients were classified based on the type of allergic diseases and analyzed. Fourth, the association of the complexity of allergic diseases with liver cancer was further investigated.

Statistical significance was defined as a 2-sided $P$ value of $<0.05$. During study, data collection and statistical analyses were performed by using SAS 9.4 (SAS Institute, Cary, NC, USA) and STATA 13.0(StataCrop LP, College Station, TX, USA).

\section{Results}

Descriptive characteristics of the study population are depicted in Table 1. Among the overall cohort of 405,512 participants, there were 338,239 without history of allergies and 67,279 with documented allergic diseases. 3,059 (0.75\%), 21,487 (5.30\%), and 49,716 (12.26\%) participants had atopic dermatitis, asthma, and allergic rhinitis, respectively. Some participants had multiple allergies and were included in more than one allergic disease categories. Compared with participants who have not been diagnosed with allergic diseases, patients with allergic diseases tended to be older, female, smoke less, consume less alcohol, have more comorbidities and higher prevalence of HBV/HCV infection. 
Table 1

Descriptive characteristics of the study population.

\begin{tabular}{|c|c|c|c|c|c|c|}
\hline & Total & $\begin{array}{l}\text { Non-allergic } \\
\text { patients }\end{array}$ & $\begin{array}{l}\text { Allergic } \\
\text { patients }\end{array}$ & $\begin{array}{l}\text { Atopic } \\
\text { dermatitis }\end{array}$ & Asthma & $\begin{array}{l}\text { Allergic } \\
\text { rhinitis }\end{array}$ \\
\hline $\begin{array}{l}\text { Participants, } \\
\text { N (\%) }\end{array}$ & $405,518(100)$ & $338,239(83.41)$ & $67,279(16.59)$ & $3,059(0.75)$ & $21,487(5.30)$ & $49,716(12.26)$ \\
\hline \multicolumn{7}{|l|}{ Total cohort } \\
\hline \multicolumn{7}{|l|}{$\begin{array}{l}\text { Age, years, N } \\
(\%)\end{array}$} \\
\hline $40-49$ & $163,337(40.28)$ & $137,791(40.74)$ & $25,546(37.97)$ & 1,093(35.73) & $5,186(24.14)$ & $21,390(43.02)$ \\
\hline $50-59$ & $126,400(31.17)$ & $\begin{array}{l}106,714 \\
(31.55)\end{array}$ & $19,686(29.26)$ & $993(32.46)$ & $5,873(27.33)$ & $14,900(29.97)$ \\
\hline $60-69$ & $84,407(20.81)$ & $68,904(20.37)$ & $15,503(23.04)$ & $673(22.00)$ & $6,776(31.54)$ & $10,013(20.14)$ \\
\hline$\geq 70$ & $31,374(7.74)$ & $24,830(7.34)$ & $6,544(9.73)$ & $300(9.81)$ & $3,652(17.00)$ & $3,413(6.86)$ \\
\hline \multicolumn{7}{|l|}{ Sex, N (\%) } \\
\hline Men & $223,494(55.11)$ & $191,288(56.55)$ & $32,206(47.87)$ & $1,649(53.91)$ & $9,313(43.34)$ & $24,226(48.73)$ \\
\hline Women & $182,024(44.89)$ & $146,951(43.45)$ & $35,073(52.13)$ & $1,410(46.09)$ & $12,174(56.66)$ & $25,490(51.27)$ \\
\hline \multicolumn{7}{|l|}{$\begin{array}{l}\text { Household } \\
\text { income, } \\
\text { quartile, N } \\
(\%)\end{array}$} \\
\hline 1st (highest) & $141,931(35.00)$ & $117,520(34.74)$ & $24,411(36.28)$ & $1,147(37.50)$ & $6,712(31.24)$ & $19,030(38.28)$ \\
\hline 2nd & $116,551(28.74)$ & $97,371(28.79)$ & $19,180(28.51)$ & $844(27.59)$ & $6,180(28.76)$ & $14,110(28.38)$ \\
\hline $3 r d$ & $84,547(20.85)$ & $71,220(21.06)$ & $13,327(19.81)$ & 622(20.33) & $4,658(21.68)$ & $9,496(19.10)$ \\
\hline 4th (lowest) & $62,489(15.41)$ & $52,128(15.41)$ & $10,361(15.40)$ & $446(14.58)$ & 3,937(18.32) & $7,080(14.24)$ \\
\hline \multirow{2}{*}{$\begin{array}{l}\text { Charlson } \\
\text { comorbidity } \\
\text { index, N (\%) }\end{array}$} & & & & & & \\
\hline & $\begin{array}{l}282,464 \\
(69.66)\end{array}$ & $246,550(72.89)$ & $35,914(53.38)$ & $1.822(59.56)$ & $7,319(34.06)$ & $29,219(58.77)$ \\
\hline$>1$ & $123,054(30.34)$ & $91,689(27.11)$ & $31,365(46.62)$ & $1,237(40.44)$ & $14,168(65.94)$ & $20,497(41.23)$ \\
\hline \multicolumn{7}{|l|}{$\begin{array}{l}\text { History of } \\
\text { HBV/HCV } \\
\text { infection, N } \\
(\%) * \star\end{array}$} \\
\hline No & $397,868(98.11)$ & $332,055(98.17)$ & $65,813(97.82)$ & $2,990(97.74)$ & $21,036(97.90)$ & $48,598(97.75)$ \\
\hline Yes & $7,650(1.89)$ & $6,184(1.83)$ & $1,466(2.18)$ & $69(2.26)$ & $451(2.10)$ & $1,118(2.25)$ \\
\hline $\begin{array}{l}\text { History of } \\
\text { liver } \\
\text { cirrhosis, N } \\
(\%)\end{array}$ & & & & & & \\
\hline
\end{tabular}

* Participants with lifestyle related variables missing are marked

** Having a history of hepatitis B/C virus infection was defined as having a disease code of either hepatitis B or hepatitis $\mathrm{C}$ described in the medical record of the participant. 


\begin{tabular}{|c|c|c|c|c|c|c|}
\hline & Total & $\begin{array}{l}\text { Non-allergic } \\
\text { patients }\end{array}$ & $\begin{array}{l}\text { Allergic } \\
\text { patients }\end{array}$ & $\begin{array}{l}\text { Atopic } \\
\text { dermatitis }\end{array}$ & Asthma & $\begin{array}{l}\text { Allergic } \\
\text { rhinitis }\end{array}$ \\
\hline No & $403,424(99.48)$ & $336,484(99.48)$ & $66,940(99.50)$ & $3,041(99.41)$ & $21,362(99.42)$ & $49,481(99.53)$ \\
\hline Yes & $2,094(0.52)$ & $1,755(0.52)$ & $339(0.50)$ & 18(0.59) & $125(0.58)$ & $235(0.47)$ \\
\hline \multicolumn{7}{|c|}{ Health Screening Cohort } \\
\hline $\begin{array}{l}\text { Body mass } \\
\text { index, } \mathrm{kg} / \mathrm{m}^{2} \\
\text { mean }(\mathrm{SD})\end{array}$ & 23.98 & 23.97 & 24.03 & 23.96 & 24.19 & 23.99 \\
\hline $\begin{array}{l}\text { Systolic } \\
\text { blood } \\
\text { pressure, } \\
\text { mmHg, } \\
\text { mean (SD) }\end{array}$ & 127.19 & 127.37 & 126.29 & 127.40 & 128.50 & 125.36 \\
\hline $\begin{array}{l}\text { Total } \\
\text { cholesterol, } \\
\text { mg/dL, } \\
\text { mean (SD) }\end{array}$ & 199.68 & 199.52 & 200.47 & 202.00 & 201.93 & 200.03 \\
\hline $\begin{array}{l}\text { Fasting } \\
\text { serum } \\
\text { glucose, } \\
\text { mg/dL, } \\
\text { mean (SD) }\end{array}$ & 98.16 & 98.42 & 96.82 & 97.40 & 98.46 & 96.10 \\
\hline \multicolumn{7}{|l|}{$\begin{array}{l}\text { Smoking } \\
\text { status, N (\%) }\end{array}$} \\
\hline $\begin{array}{l}\text { Never } \\
\text { smoker }\end{array}$ & $261,512(65.47)$ & $217,567(64.32)$ & $47,945(71.26)$ & $2,038(66.62)$ & $15,556(72.40)$ & $35,564(71.53)$ \\
\hline $\begin{array}{l}\text { Former } \\
\text { smoker }\end{array}$ & $35,465(8.75)$ & $29,684(8.78)$ & $5,781(8.59)$ & 280(9.15) & $1,611(7.50)$ & $4,426(8.90)$ \\
\hline $\begin{array}{l}\text { Current } \\
\text { smoker }\end{array}$ & $89,888(22.17)$ & $78,781(23.29)$ & $11,107(16.51)$ & 603(19.71) & $3,559(16.56)$ & $7,909(15.91)$ \\
\hline Missing* & $14,653(3.61)$ & $12,207(3.61)$ & $2,446(3.64)$ & $138(4.51)$ & $761(3.54)$ & $1,817(3.65)$ \\
\hline \multicolumn{7}{|l|}{$\begin{array}{l}\text { Physical } \\
\text { activity, } \\
\text { times per } \\
\text { week, N (\%) }\end{array}$} \\
\hline 0 & $213,965(52.76)$ & 178,898(52.89) & $35,067(52.12)$ & $1,623(53.06)$ & $12,433(57.86)$ & $24,767(49.82)$ \\
\hline $1-2$ & $99,126(24.44)$ & $83,320(24.63)$ & $15,806(23.49)$ & $687(22.46)$ & $4,217(19.63)$ & $12,410(24.96)$ \\
\hline $3-4$ & $42,679(10.52)$ & $35,180(10.40)$ & 7,499(11.15) & $344(11.25)$ & 1,894(8.81) & $5,986(12.04)$ \\
\hline $5-6$ & $11,511(2.84)$ & $9,411(2.78)$ & $2,100(3.12)$ & $79(2.58)$ & $593(2.76)$ & 1,664(3.35) \\
\hline 7 & $29,054(7.16)$ & 23,785(7.03) & $5,269(7.83)$ & 247(8.07) & $1,808(8.41)$ & $3,810(7.66)$ \\
\hline Missing* & $9,183(2.26)$ & $7,645(2.26)$ & $1,538(2.29)$ & $79(2.58)$ & $542(2.52)$ & $1,079(2.17)$ \\
\hline
\end{tabular}

* Participants with lifestyle related variables missing are marked

** Having a history of hepatitis B/C virus infection was defined as having a disease code of either hepatitis B or hepatitis $\mathrm{C}$ described in the medical record of the participant. 


\begin{tabular}{|c|c|c|c|c|c|c|}
\hline & Total & $\begin{array}{l}\text { Non-allergic } \\
\text { patients }\end{array}$ & $\begin{array}{l}\text { Allergic } \\
\text { patients }\end{array}$ & $\begin{array}{l}\text { Atopic } \\
\text { dermatitis }\end{array}$ & Asthma & $\begin{array}{l}\text { Allergic } \\
\text { rhinitis }\end{array}$ \\
\hline \multicolumn{7}{|c|}{$\begin{array}{l}\text { Alcohol } \\
\text { consumption } \\
\text { frequency, N } \\
(\%)\end{array}$} \\
\hline 0 & $226,087(55.75)$ & $184,893(54.66)$ & $41,194(61.23)$ & 1,793(58.61) & $14,287(66.49)$ & $29,726(59.79)$ \\
\hline$<1$ & $60,796(14.99)$ & $50,904(15.05)$ & $9,892(14.70)$ & $468(15.30)$ & $2,617(12.18)$ & $7,747(15.58)$ \\
\hline $1-2$ & $67,114(16.55)$ & $57,617(17.03)$ & $9,497(14.12)$ & $461(15.07)$ & 2,430(11.31) & $7,440(14.97)$ \\
\hline $3-4$ & $27,826(6.86)$ & $24,377(7.21)$ & $3,449(5.13)$ & $183(5.98)$ & $954(4.44)$ & $2,579(5.19)$ \\
\hline$\geq 5$ & $17,150(4.23)$ & $15,004(4.44)$ & $2,146(3.19)$ & $109(3.56)$ & $817(3.80)$ & $1,438(2.89)$ \\
\hline Missing* & $6,545(1.61)$ & $5,444(1.61)$ & $1,101(1.64)$ & $45(1.47)$ & $382(1.78)$ & $786(1.58)$ \\
\hline \multicolumn{7}{|c|}{ * Participants with lifestyle related variables missing are marked } \\
\hline
\end{tabular}

Table 2 displays the association between allergic diseases and risk of liver cancer. During the follow-up period from January 1st, 2005 to December 31st, 2013, 2,040 of non-allergic patients during a 2,891,780 person-year follow up and 310 of allergic patients during a 571,605 person-year follow up experienced liver cancer. Allergic patients had significantly lower risk of overall liver cancer compared to non-allergic patients (aHR: $0.72,95 \% \mathrm{Cl}: 0.64-0.81$ ). Among the two main categories of primary liver cancer, the risk of HCC was significantly reduced in patients with allergic diseases (aHR: $0.70,95 \%$ Cl: 0.61 0.81 ) but the risk of ICC had no association with allergic diseases (aHR: $0.99,95 \%$ Cl: 0.71-1.08). 
Association of the history of allergic diseases with risk of liver cancer incidence.

\begin{tabular}{|c|c|c|}
\hline & Non-allergic patients & Allergic patients \\
\hline \multicolumn{3}{|l|}{ Overall } \\
\hline Events, N (\%) & $2,045(0.60)$ & $310(0.46)$ \\
\hline Person-years & $2,891,780$ & 571,604 \\
\hline aHR $(95 \% \mathrm{Cl})$ & 1.00(Reference) & $0.72(0.64-0.81)$ \\
\hline \multicolumn{3}{|l|}{$\mathrm{HCC}$} \\
\hline Events, N (\%) & $1,643(0.49)$ & $239(0.36)$ \\
\hline aHR $(95 \% \mathrm{Cl})$ & 1.00(Reference) & $0.70(0.61-0.81)$ \\
\hline \multicolumn{3}{|l|}{ ICC } \\
\hline Events, N (\%) & $550(0.16)$ & $104(0.15)$ \\
\hline aHR $(95 \% \mathrm{Cl})$ & 1.00(Reference) & $0.88(0.71-1.08)$ \\
\hline \multicolumn{3}{|c|}{$\begin{array}{l}\text { Hazard ratio calculated by Cox proportional hazards regression analysis after adjustments for age, sex, body mass } \\
\text { index, Charlson comorbidity index, household income, smoking, alcohol consumption, physical activity, systolic blood } \\
\text { pressure, fasting serum glucose, total cholesterol, history of hepatitis B virus/hepatitis C virus infection and liver } \\
\text { cirrhosis. }\end{array}$} \\
\hline
\end{tabular}

According to all covariates included in this study, stratified analyses were performed and plotted as shown in Figure 2. In all sub-group analyses, allergic patients show reduced hazard ratios for liver cancer. Mostly there was no significant interactions between allergic state and the risk of liver cancer across prespecified variables. In health screening cohort, bmi, fasting glucose serum and alcohol consumption frequency which are risk factors fatty liver diseases showed decreased hazard ratios regardless of the history of allergic diseases. ${ }^{15,16}$ The aHR $(95 \% \mathrm{Cl})$ for liver cancer of allergic patients infected and not infected with HBV/HCV were $0.61(0.47-0.8)$ and $0.74(0.65-0.85)$ respectively. Presence of allergies was associated with significantly lower risk of liver cancer among patients without cirrhosis (aHR: 0.72, 95\% Cl: 0.62-0.82), but this effect was not observed among patients with cirrhosis (aHR: 0.98, 95\% Cl: 0.68-1.41). Participants were further classified and analyzed depending on the types of allergic diseases in Table 3 . The resulting aHR $(95 \% \mathrm{Cl})$ of patients with atopic dermatitis, asthma and allergic rhinitis were $0.79(0.48-1.32), 0.76(0.63-0.92)$ and $0.71(0.61-0.84)$. 
Table 3

Association of allergic diseases with risk of liver cancer

\begin{tabular}{|c|c|c|c|c|c|c|}
\hline & $\begin{array}{l}\text { Non-atopic } \\
\text { dermatitis }\end{array}$ & $\begin{array}{l}\text { Atopic } \\
\text { dermatitis }\end{array}$ & Non-asthma & Asthma & $\begin{array}{l}\text { Non-allergic } \\
\text { rhinitis }\end{array}$ & $\begin{array}{l}\text { Allergic } \\
\text { rhinitis }\end{array}$ \\
\hline $\begin{array}{l}\text { Events, } N \\
(\%)\end{array}$ & $2,340(0.58)$ & $15(0.49)$ & $2,233(0.58)$ & $122(0.57)$ & $2,152(0.60)$ & $203(0.41)$ \\
\hline $\begin{array}{l}\text { Person- } \\
\text { years }\end{array}$ & $3,437,420$ & 25,964 & $3,285,866$ & 177,518 & $3,036,424$ & 426,961 \\
\hline $\begin{array}{l}\text { aHR }(95 \% \\
\mathrm{Cl})\end{array}$ & 1.00(Reference) & $\begin{array}{l}0.79(0.48- \\
1.32)\end{array}$ & 1.00(Reference) & $\begin{array}{l}0.76(0.63- \\
0.92)\end{array}$ & 1.00(Reference) & $\begin{array}{l}0.71(0.61- \\
0.82)\end{array}$ \\
\hline
\end{tabular}

Finally, we investigated differences in liver cancer risk among patients with single allergic disease and those with multiple allergic diseases (Table 4). Compared to patients with no history of allergies, aHRs(95\% Cl) of 'atopic dermatitis only', 'asthma only, 'allergic rhinitis only', and 'two or more allergy' were $0.86(0.50-1.48), 0.77(0.62-0.95), 0.71(0.60-0.83)$, and $0.62(0.43-0.89)$, respectively. Patients with multiple allergic diseases had the lowest risk of liver cancer contrast to those with single allergic disease.

Table 4

Association of allergic disease incidence with risk of liver cancer incidence.

\begin{tabular}{|c|c|c|c|c|c|}
\hline & $\begin{array}{l}\text { No allergic } \\
\text { history }\end{array}$ & $\begin{array}{l}\text { Atopic dermatitis } \\
\text { only }\end{array}$ & Asthma only & $\begin{array}{l}\text { Allergic rhinitis } \\
\text { only }\end{array}$ & $\underset{\star}{\text { Two or more allergies }}$ \\
\hline $\begin{array}{l}\text { Events, } \mathrm{N} \\
(\%)\end{array}$ & $2,045(0.60)$ & $13(0.57)$ & $94(0.62)$ & $174(0.40)$ & $29(0.42)$ \\
\hline $\begin{array}{l}\text { Person- } \\
\text { years }\end{array}$ & $2,891,780$ & 19,217 & 124,203 & 370,200 & 57,985 \\
\hline $\begin{array}{l}\text { aHR }(95 \% \\
\mathrm{Cl})\end{array}$ & 1.00(Reference) & $0.86(0.50-1.48)$ & $\begin{array}{l}0.77(0.62- \\
0.95)\end{array}$ & $0.71(0.60-0.83)$ & $0.62(0.43-0.89)$ \\
\hline \multicolumn{6}{|c|}{$\begin{array}{l}\text { Hazard ratio calculated by Cox proportional hazards regression analysis after adjustments for age, sex, body mass } \\
\text { index, Charlson comorbidity index, household income, smoking, alcohol consumption, physical activity, systolic blood } \\
\text { pressure, fasting serum glucose, total cholesterol, history of hepatitis B virus/hepatitis C virus infection and liver } \\
\text { cirrhosis. }\end{array}$} \\
\hline
\end{tabular}

\section{Discussion}

Our large, population-based longitudinal retrospective cohort study has demonstrated the protective effect of allergic diseases on the risk of developing liver cancer, specifically HCC. This phenomenon was observed across different types of allergic diseases, and especially more pronounced among those with multiple allergic diseases who presumably have more severe allergies. To our knowledge, this is the first study which clarified the association of allergic disease with risk of HCC by adjusting not only for strong risk factors such as HBV/HCV infection and liver cirrhosis but also BMI, fasting glucose serum, and alcohol consumption frequency which are associated with alcoholic and non-alcoholic fatty liver diseases.

The protective effect of allergic diseases was limited to patients without cirrhosis, and presence of allergic diseases was not associated with reduction of HCC risk among patients with cirrhosis. This is likely due to the irreversible damage and 
fibrosis that have taken place in a cirrhotic liver, which predisposes to development of HCC. ${ }^{17}$ Moreover, cirrhosis affects innate immunity by impairing the synthesis and function of related proteins. ${ }^{18}$ This may attenuate the allergy-driven immune responses within the liver and remove the protective effects of allergic diseases.

Many epidemiologic studies have shown an inverse relationship between cancer incidence and presence of allergic diseases in various types of cancers. The strong and negative association of allergic diseases with cancer risk particularly for pancreatic cancer, brain cancers, hematological cancers and gastrointestinal cancers was well addressed in several studies. ${ }^{19}$ Some studies showed more highlighted significantly reduced risk. A history of allergic diseases has associated with a decreased risk of pancreatic cancer $(\mathrm{OR}=0.58 ; 95 \% \mathrm{Cl}, 0.40-0.84) .{ }^{20} \mathrm{~A}$ history of self-reported allergy and/or asthma was inversely associated with risk of meningioma $(\mathrm{OR}=0.6 ; 95 \% \mathrm{Cl}, 0.5-0.7$ for self-reported allergy, OR=0.7; $95 \%$ $\mathrm{Cl}, 0.6-0.9$ for asthma) and anaplastic oligodendroglioma $(\mathrm{OR}=0.6 ; 95 \% \mathrm{Cl}, 0.4-0.9) .{ }^{21,22} \mathrm{~A}$ meta-analysis reported the inverse association of a history of allergy $(\mathrm{OR}=0.69195 \% \mathrm{Cl}, 0.54-0.89)$, eczema $(\mathrm{OR}=0.74 ; 95 \% \mathrm{Cl}, 0.58-0.96)$ and hay fever $(\mathrm{OR}=0.55 ; 95 \% \mathrm{Cl}, 0.46-0.66)$ with childhood/adolescent acute lymphoblastic leukemia. ${ }^{23}$ In a large case-control study, the protective effect of prior history of allergic diseases on risk of both colonic $(\mathrm{OR}=0.75,95 \% \mathrm{Cl}, 0.59-0.97)$ and rectal cancers(OR=0.54, 95\% Cl, 0.37-0.77) was observed. ${ }^{24}$ Moreover, a significantly reduced risk of gastric cancer(OR=0.27; $95 \%$ $\mathrm{Ci}, 0.1-0.9)$ was also observed in patients with a self-reported prior diagnosis of asthma. ${ }^{25}$

There are several underlying mechanisms that explain why allergic patients might be protected against cancer development. Two of the leading hypotheses include immunosurveillance and prophylaxis. ${ }^{26}$ The "immunosurveillance hypothesis" explains that since allergy is a consequence of improved and hyper-responsive immune system, which enables easy recognition and capture of dysregulated or damaged cells and even cancer cells. ${ }^{7}$ According to the "prophylaxis hypothesis", allergic reaction is considered to be the body's way of expelling carcinogens before malignant transformation. ${ }^{27}$ The scientific background of evolutionary biology further indicates that allergy and cancer are inversely correlated. Due to the increased awareness of hygiene, the lack of exposure to infectious agents in the industrialized countries increases sensitivity to other non-infectious agents and it brings Th2 type immune reaction against environmental factors with IgE production. That is, allergic responses could have evolved as an immunological adaptation and allergens could be substitutes for other presumed noxious agents. ${ }^{28}$ Evolutionary biology implies that during allergic responses, released IgE engages in tumor surveillance and is exploited for tumor control in either active or passive ways. ${ }^{29}$ Notably, the inverse relationship between cancer risk and allergic diseases appears more prominent in malignancies of tissues or organs interfacing the external environment such as cancers of the gastrointestinal tract. ${ }^{27}$

With regards to HCC, which is categorized as a malignancy of the gastrointestinal tract, reduced risk in allergic patients can be further explained through immunological perspectives. Liver is an immune organ which contains both innate and adaptive immune cells, and plays an important role in producing cytokines and maintaining the balance between immunotolerance and activation of the immune system. ${ }^{30,31}$ Allergic diseases induce immune responses which provoke immune effector cells to be activated and produce cytokines which leads to immunosurveillance. Previous studies suggested that stimulated immune responses by allergic diseases activate mast cells and NK cells so that it results in the protection against liver cancer. ${ }^{32-35}$ Also, some studies indicated that released cytokines during allergic responses such as IL-6 and IL-33 could be predictive factors for survival in HCC patients. ${ }^{36-39}$

There are several limitations to be considered in our study. First, the definition of allergic diseases was determined by ICD10 code and we did not analyze disease severity based on doses of drugs and laboratory data such as serum IgE levels and skin prick test. Future studies utilizing a better defined cohort of allergic patients who are diagnosed using goldstandard methods will be needed. Second, this study was conducted only with the South Korean population which may limit its generalizability. Future studies with a more diverse population are required to further certify the findings from this study. Third, the definition of liver cancer could not be validated by registered medical records. Even though we adopted the 
operational definition for liver cancer from previous studies that also used NHIS database ${ }^{40}$, future studies with more optimized definition of liver cancer are needed.

Nonetheless, our study has several strengths. First, we adjusted all possible risk factors for liver cancer including HBV/HCV infection, history of liver cirrhosis, bmi, fasting serum glucose and alcohol consumption so that this study could represent more validated relationship between allergic disease and liver cancer compared to previous studies. Second, the length of our study duration and large size of study population further validate the reliability of our results. Third, we further performed several sub-analyses to highlight the correlation of allergic diseases with risk of liver cancer.

Immunotherapy harnesses the immune system to recognize and attack cancer cells and emerging as a promising treatment for liver cancer. However, many immunotherapeutic approaches are still underway to verify its clinical applicability for the treatment of liver cancer. ${ }^{41}$ Our findings which demonstrated the association between IgE-mediated allergic responses and decreased risk of liver cancer support the validity of immunotherapy in liver cancer and encourage more clinical trials to achieve successful treatment of liver cancer.

\section{Conclusions}

We have elucidated the association of allergic diseases and HCC risk in detailed and specific manner by adjusting potential risk factors and conducting sub-analyses. This finding supports the rationale for utilizing immunotherapy as a potent treatment option for HCC. Further investigation of allergic diseases and their role in immunosurveillance and prophylaxis against HCC may lead to development of additional therapeutic and preventative options.

\section{Abbreviations}

$\mathrm{N}$, number of people; aHR, adjusted hazard ratio; $\mathrm{Cl}$, confidential interval; HCC, Hepatocellular carcinoma; ICC, intrahepatic cholangiocarcinoma; SD, standard deviation; HBV, hepatitis B virus; HCV, hepatitis C virus; OD, odds ratio.

\section{Declarations}

\section{Consent for publication}

Not applicable.

\section{Availability of data and materials}

The data that support the findings of this study are available from the Korean NHIS but restrictions apply to the availability of these data, which were used under license for the current study, and so are not publicly available. Data are however available from the authors upon reasonable request and with permission of the Korean NHIS.

\section{Competing interests}

None of the authors have any conflicts to report.

\section{Author Contributions:}

Study concept and design: JS Son, SM Park

Acquisition of data: SM Park

Page $11 / 15$ 
Analysis and interpretation of data: JA Kim, S Choi, J Chang, S Jeong, JC Ahn, G Lee

Drafting of the manuscript: JA Kim

Critical revision of the manuscript: JA Kim, S Choi, J Chang, JC Ahn, S Jeong, JS Son

Statistical analysis: JA Kim

\section{References}

1. Kim BH, Park JW. Epidemiology of liver cancer in South Korea. Clin Mol Hepatol. Mar 2018;24(1):1-9. doi:10.3350/cmh.2017.0112

2. Yamashita T, Kaneko S. [Liver Cancer]. Rinsho Byori. Jul 2016;64(7):787-796.

3. Anwanwan D, Singh SK, Singh S, Saikam V, Singh R. Challenges in liver cancer and possible treatment approaches. Biochim Biophys Acta Rev Cancer. Jan 2020;1873(1):188314. doi:10.1016/j.bbcan.2019.188314

4. Gryziak M, Woźniak K, Kraj L, Stec R. Milestones in the treatment of hepatocellular carcinoma: A systematic review. Crit Rev Oncol Hematol. Jan 2021;157:103179. doi:10.1016/j.critrevonc.2020.103179

5. Wu LC, Zarrin AA. The production and regulation of IgE by the immune system. Nat Rev Immunol. Apr 2014;14(4):24759. doi:10.1038/nri3632

6. Leoh LS, Daniels-Wells TR, Penichet ML. IgE immunotherapy against cancer. Curr Top Microbiol Immunol. 2015;388:109-149. doi:10.1007/978-3-319-13725-4_6

7. Karim AF, Westenberg LEH, Eurelings LEM, Otten R, Gerth van Wijk R. The association between allergic diseases and cancer: a systematic review of the literature. Neth J Med. Feb 2019;77(2):42-66.

8. La Vecchia C, Negri E, D'Avanzo B, Boyle P, Franceschi S. Medical History and Primary Liver Cancer. Cancer Research. 1990;50(19):6274-6277.

9. Cancer Epidemiology Biomarkers \& Prevention. 2019;28(4):741-750. doi:10.1158/1055-9965.Epi-18-0887

10. Hemminki K, Försti A, Fallah M, Sundquist J, Sundquist K, Ji J. Risk of cancer in patients with medically diagnosed hay fever or allergic rhinitis. International Journal of Cancer. 2014;135(10):2397-2403.

doi:https://doi.org/10.1002/ijc.28873

11. Cheol Seong S, Kim YY, Khang YH, et al. Data Resource Profile: The National Health Information Database of the National Health Insurance Service in South Korea. Int J Epidemiol. Jun 1 2017;46(3):799-800. doi:10.1093/ije/dyw253

12. Seong SC, Kim YY, Park SK, et al. Cohort profile: the National Health Insurance Service-National Health Screening Cohort (NHIS-HEALS) in Korea. BMJ Open. Sep 24 2017;7(9):e016640. doi:10.1136/bmjopen-2017-016640

13. Lapointe-Shaw L, Georgie F, Carlone D, et al. Identifying cirrhosis, decompensated cirrhosis and hepatocellular carcinoma in health administrative data: A validation study. PLoS One. 2018;13(8):e0201120.

doi:10.1371/journal.pone.0201120

14. Sundararajan V, Henderson T, Perry C, Muggivan A, Quan H, Ghali WA. New ICD-10 version of the Charlson comorbidity index predicted in-hospital mortality. J Clin Epidemiol. Dec 2004;57(12):1288-94. doi:10.1016/j.jclinepi.2004.03.012

15. Fabbrini E, Sullivan S, Klein S. Obesity and nonalcoholic fatty liver disease: Biochemical, metabolic, and clinical implications. Hepatology. 2010;51(2):679-689. doi:https://doi.org/10.1002/hep.23280

16. Estep MJ, Matharoo G, Hossain N, et al. Elevated Fasting Serum Glucose in Non-Alcoholic Fatty Liver Disease (NAFLD) Patients is Correlated with the Degree of Steatosis: 393. Official journal of the American College of Gastroenterology I ACG. 2012;107:S166.

17. Ito K, Mitchell DG. Imaging diagnosis of cirrhosis and chronic hepatitis. Intervirology. 2004;47(3-5):134-43. doi:10.1159/000078465

Page $12 / 15$ 
18. Noor MT, Manoria P. Immune Dysfunction in Cirrhosis. J Clin Transl Hepatol. Mar 28 2017;5(1):50-58. doi:10.14218/jcth.2016.00056

19. Josephs DH, Spicer JF, Corrigan CJ, Gould HJ, Karagiannis SN. Epidemiological associations of allergy, IgE and cancer. Clinical \& Experimental Allergy. 2013;43(10):1110-1123. doi:https://doi.org/10.1111/cea.12178

20. Olson SH, Orlow I, Simon J, et al. Allergies, variants in IL-4 and IL-4R alpha genes, and risk of pancreatic cancer. Cancer Detect Prev. 2007;31(5):345-51. doi:10.1016/j.cdp.2007.10.002

21. Claus EB, Calvocoressi L, Bondy ML, Schildkraut JM, Wiemels JL, Wrensch M. Family and personal medical history and risk of meningioma. Journal of Neurosurgery JNS. 01 Dec. 2011 2011;115(6):1072. doi:10.3171/2011.6.Jns11129

22. McCarthy BJ, Rankin KM, Aldape K, et al. Risk factors for oligodendroglial tumors: a pooled international study. Neuro Oncol. Feb 2011;13(2):242-50. doi:10.1093/neuonc/noq173

23. Linabery AM, Jurek AM, Duval S, Ross JA. The association between atopy and childhood/adolescent leukemia: a meta-analysis. Am J Epidemiol. Apr 1 2010;171(7):749-64. doi:10.1093/aje/kwq004

24. Bosetti C, Talamini R, Franceschi S, Negri E, Giacosa A, La Vecchia C. Allergy and the risk of selected digestive and laryngeal neoplasms. Eur J Cancer Prev. Jun 2004;13(3):173-6. doi:10.1097/01.cej.0000130016.85687.cf

25. El-Zein M, Parent ME, Kâ K, Siemiatycki J, St-Pierre Y, Rousseau MC. History of asthma or eczema and cancer risk among men: a population-based case-control study in Montreal, Quebec, Canada. Ann Allergy Asthma Immunol. May 2010;104(5):378-84. doi:10.1016/j.anai.2010.03.003

26. By Paul W. Sherman, Erica Holland a, Sherman Janet S. Allergies: Their Role in Cancer Prevention. The Quarterly Review of Biology. 2008;83(4):339-362. doi:10.1086/592850

27. Fereidouni M, Ferns GA, Bahrami A. Current status and perspectives regarding the association between allergic disorders and cancer. IUBMB Life. 2020;72(7):1322-1339. doi:https://doi.org/10.1002/iub.2285

28. Daschner A, González Fernández J. Allergy in an Evolutionary Framework. Journal of Molecular Evolution. 2020/01/01 2020;88(1):66-76. doi:10.1007/s00239-019-09895-3

29. Jensen-Jarolim E, Achatz G, Turner MC, et al. AllergoOncology: the role of IgE-mediated allergy in cancer. Allergy. Oct 2008;63(10):1255-66. doi:10.1111/j.1398-9995.2008.01768.x

30. Ringelhan M, Pfister D, O'Connor T, Pikarsky E, Heikenwalder M. The immunology of hepatocellular carcinoma. Nature Immunology. 2018/03/01 2018;19(3):222-232. doi:10.1038/s41590-018-0044-z

31. Robinson MW, Harmon C, O'Farrelly C. Liver immunology and its role in inflammation and homeostasis. Cell Mol Immunol. May 2016;13(3):267-76. doi:10.1038/cmi.2016.3

32. Rohr-Udilova N, Klinglmüller F, Schulte-Hermann R, et al. Deviations of the immune cell landscape between healthy liver and hepatocellular carcinoma. Scientific Reports. 2018/04/18 2018;8(1):6220. doi:10.1038/s41598-018-24437-5

33. Singer J, Jensen-Jarolim E. IgE-based Immunotherapy of Cancer -A Comparative Oncology Approach. J Carcinog Mutagen. May 31 2014;5(3):1000176. doi:10.4172/2157-2518.1000176

34. Deniz G, van de Veen W, Akdis M. Natural killer cells in patients with allergic diseases. J Allergy Clin Immunol. Sep 2013;132(3):527-535. doi:10.1016/j.jaci.2013.07.030

35. Wei H, Fu B. Make killers sweeter: targeting metabolic checkpoints of NK cells. Nature Immunology. 2020/09/01 2020;21(9):970-971. doi:10.1038/s41590-020-0738-x

36. Lin YL, Chen SH, Wang JY. Critical role of IL-6 in dendritic cell-induced allergic inflammation of asthma. J Mol Med (Berl). Jan 2016;94(1):51-9. doi:10.1007/s00109-015-1325-8

37. Lee HL, Jang JW, Lee SW, et al. Inflammatory cytokines and change of Th1/Th2 balance as prognostic indicators for hepatocellular carcinoma in patients treated with transarterial chemoembolization. Scientific Reports. 2019/03/01 2019;9(1):3260. doi:10.1038/s41598-019-40078-8

Page $13 / 15$ 
38. Chan BCL, Lam CWK, Tam L-S, Wong CK. IL33: Roles in Allergic Inflammation and Therapeutic Perspectives. Review. Frontiers in Immunology. 2019-March-04 2019;10(364)doi:10.3389/fimmu.2019.00364

39. Jin Z, Lei L, Lin D, et al. IL-33 Released in the Liver Inhibits Tumor Growth via Promotion of CD4(+) and CD8(+) T Cell Responses in Hepatocellular Carcinoma. J Immunol. Dec 15 2018;201(12):3770-3779. doi:10.4049/jimmunol.1800627

40. Sinn DH, Kang D, Kang M, et al. Late presentation of hepatitis B among patients with newly diagnosed hepatocellular carcinoma: a national cohort study. BMC Cancer. 2019/03/29 2019;19(1):286. doi:10.1186/s12885-019-5508-5

41. Nakano S, Eso Y, Okada H, Takai A, Takahashi K, Seno H. Recent Advances in Immunotherapy for Hepatocellular Carcinoma. Cancers (Basel). Mar 25 2020;12(4)doi:10.3390/cancers12040775

\section{Figures}

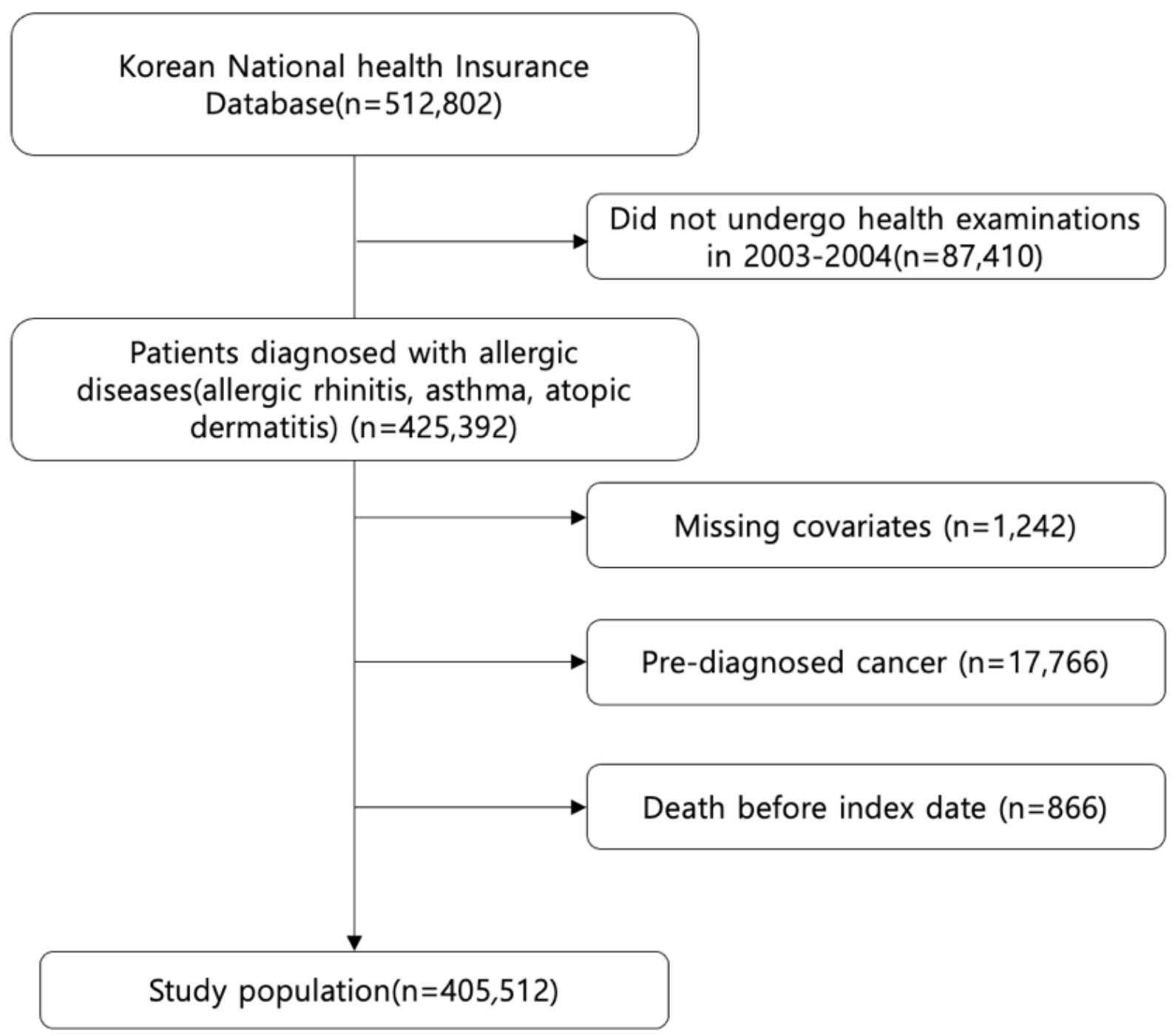

Figure 1 
Flow diagram of the study population.

\begin{tabular}{|c|c|c|c|c|c|}
\hline \multirow{2}{*}{$\begin{array}{l}\text { Subgroup } \\
\text { CCI }\end{array}$} & & \multirow[t]{2}{*}{ HR } & \multicolumn{2}{|c|}{$95 \% \mathrm{CI}$} & \multirow[t]{2}{*}{$P$ for interaction } \\
\hline & I & & & & \\
\hline$\leq 1$ & $\longrightarrow-1$ & 0.84 & 0.69 & 1.02 & 0.318 \\
\hline$>1$ & $=-i$ & 0.73 & 0.62 & 0.85 & \\
\hline BMI & $i$ & & & & \\
\hline$<25.0$ & $\rightarrow-$ & 0.7 & 0.6 & 0.82 & 0.775 \\
\hline$\geq 25.0$ & $=1$ & 0.75 & 0.61 & 0.92 & \\
\hline Systolic blood pressure & i & & & & \\
\hline$<140 \mathrm{mmHg}$ & $\rightarrow-$ & 0.67 & 0.57 & 0.78 & 0.1 \\
\hline$\geq 140 \mathrm{mmHg}$ & $\longrightarrow \quad 1$ & 0.83 & 0.68 & 1.01 & \\
\hline Total cholesterol & ! & & & & \\
\hline$<200 \mathrm{mg} / \mathrm{dl}$ & $\rightarrow-$ & 0.67 & 0.58 & 0.77 & 0.103 \\
\hline$\geq 200 \mathrm{mg} / \mathrm{dl}$ & $\Longrightarrow \quad 1$ & 0.83 & 0.67 & 1.04 & \\
\hline Fasting serum glucose & i & & & & \\
\hline$<100 \mathrm{mg} / \mathrm{dl}$ & $\rightarrow \quad i$ & 0.7 & 0.6 & 0.82 & 0.837 \\
\hline$\geq 100 \mathrm{mg} / \mathrm{dl}$ & $=\quad 1$ & 0.74 & 0.61 & 0.89 & \\
\hline Smoking status & 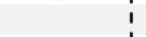 & & & & \\
\hline Never & - & 0.71 & 0.61 & 0.84 & 0.637 \\
\hline Former/current & $\longrightarrow-1$ & 0.77 & 0.64 & 0.93 & \\
\hline
\end{tabular}

\section{Figure 2}

Stratified analysis on the association of the history of allergic diseases with the risk of liver cancer

Hazard ratio calculated by Cox proportional hazards regression analysis after adjustments for age, sex, body mass index, Charlson comorbidity index, household income, smoking, alcohol consumption, physical activity, systolic blood pressure, fasting serum glucose, total cholesterol, history of hepatitis B virus/hepatitis C virus infection and liver cirrhosis. 